\title{
Rate of Wound Infection of Non-traumatic Emergency Laparotomy at a Teaching Hospital in Bangladesh: Experience of 100 cases
}

\author{
Din Mohammad ${ }^{1}$, Mahbuba Begum ${ }^{2}$, Abdur Rabban Talukder ${ }^{3}$, Md. Abdus Salam ${ }^{4}$
}

\begin{abstract}
${ }^{1}$ Assistant Professor, Department of Surgery, Shaheed Suhrawardy Medical College, Dhaka, Bangladesh; ${ }^{2}$ Assistant Professor, Department of Surgery, Medical College for Women \& Hospital, Dhaka, Bangladesh; ${ }^{3}$ Assistant Professor, Department of Surgery, Shaheed Mansur Ali Medical College, Sirajgonj, Bangladesh; ${ }^{4}$ Associate Professor, Department of Neuro-trauma Surgery, National Institute of Neurosciences \& Hospital, Dhaka, Bangladesh
\end{abstract}

[Received: 1 January 2015; Accepted: 15 March 2015; Published: 1 June 2015]

\begin{abstract}
Background: Wound infection is an important issue for surgical operations. Objective: The purpose of the present study was to measure the rate of wound infection of non-traumatic emergency laparotomy cases. Methodology: This descriptive cohort study was carried out in the Department of Surgery at Dhaka Medical College, Dhaka from July 1997 to June 1998 for a period of 1(one) year. Pre-operative patients were carefully assessed for any host factors related to wound infection. Different per-operative factors that influence the rate of postoperative wound infection were also analyzed. Swabs were taken from the suspected postoperative wound and sent for bacteriological examination. Result: In this series, 100 cases of emergency laparotomies (non-traumatic) were analyzed. Bacteriological examination showed positive culture in most of the cases but three were found to be negative result. Wound infection rate of specific type of operation were $12.5 \%, 20.0 \%, 6.6 \%, 40.0 \%, 40.0 \%, 33.3 \%, 50.0 \%, 50.0 \%$, and $100.0 \%$ in duodenal ulcer perforation, pre-pyloric and gastric ulcer perforation, acute appendicitis, burst appendix, ileal perforation, small intestinal obstruction due to bands and adhesions, volvulus of sigmoid colon, obstructed inguinal hernia, generalized peritonitis due to puerperal sepsis respectively. The overall surgical wound infection rate was $19.0 \%$. Conclusion: The rate of wound infection of non-traumatic emergency laparotomy cases are frequently found in a well-established tertiary care teaching hospital. [Bangladesh J Infect Dis 2015;2(1):912]

Keywords: Wound Infection; non-traumatic; emergency laparotomy

[How to Cite this article: Mohammad D, Begum M, Talukder AR, Salam AB. Rate of Wound Infection of Non-traumatic Emergency Laparotomy at a Teaching Hospital in Bangladesh: Experience of 100 cases. Bangladesh J Infect Dis 2015;2(1):9-12]

Corresponding author: Dr. Din Mohammad, Assistant Professor, Department of Surgery, Shaheed Suhrawardy Medical College, Dhaka, Bangladesh; Email: dr.din zip@yahoo.com ; Cell no.: +8801715063472

Conflict of Interest: Authors have declared no conflict of interest.

Contributions to authors: DM has contributed from protocol preparation to manuscript writing as well as in data collection. MB \& ART \& ABS have prepared and have revised the manuscript.
\end{abstract}

\section{Introduction}

Wound infection continues to be a major source of morbidity in surgical patients ${ }^{1}$. Wound infection may be responsible for the failure of an operation to achieve its purpose. It also results in tremendous loss of time and money due to prolonged period of healing. The main determinants of infection are the micro-organisms, the environment and the host defense mechanisms. There is a continuous 
interaction between these three factors ${ }^{2}$. Infection rates are known to be higher in emergency surgery. However it has not been clearly defined whether this is because patients undergoing emergency procedures have a higher intra-operative wound contamination. Other factors involved include the presence of obesity, malnutrition, COPD, diabetes mellitus or pre-operative use of steroids, duration of surgery and age and sex of the patients ${ }^{3}$.

Wound infections usually appear between 5 th and 10th days after surgery but they may appear as early as the $1^{\text {st }}$ postoperative day or even years later ${ }^{4}$. The first sign of wound infection is usually fever. The patient may complain of wound pain. Postoperative fever requires inspection of the wound and if wound is infected, appropriate management needs to be initiated. Therefor the present study was carried out to measure the rate of wound infection of nontraumatic emergency laparotomy surgeries.

\section{Methodology}

This descriptive cohort study was carried out in the Department of Surgery at Dhaka Medical College, Dhaka from July 1997 to June 1998 for a period of 1 (one) year. In this study, 100 patients selected at random from different surgical units of Dhaka Medical College Hospital were included. All the patients studied were admitted for emergency surgery for acute appendicitis, perforated peptic ulcer, ileal perforation, acute intestinal obstruction and generalized peritonitis due to puerperal sepsis. Specimens were collected for bacteriological study aseptically by cotton wool swab stick enclosed in sterile tube. The specimens were sent to the laboratory after proper labeling. Swabs were taken from the discharge in the postoperative wound. Swabs were plated on blood agar media and MacConkey's media. The plates were incubated aerobically at $37^{\circ} \mathrm{C}$ for 24 hours. After 24 hours culture plates were examined and some were subculture for next 24 hours aerobically. Antibiotic sensitivity test was carried out by impregnated disc techniques. Detailed history was taken and clinical examination done on every patient immediately after admission. But if needed, immediate resuscitative measures were instituted first. Particular attention was paid to the diabetic status, drug use especially steroids or any immunosuppressive drugs and presence of concurrent disease. The clinical examination stressed particular vital parameters, general physical build, nutritional status, anaemia, jaundice and any septic focus. Relevant diagnostic investigations as far as possible were done and recorded. During shaving ordinary soap was used. In the operation theatre, after anaesthesia skin was cleaned with Povidone iodine USP 5\% wlw and then Spirit (70\% methylated spirit in water). In some cases only povidone iodine was used. Every effort was made to protect the wound margin from contamination when entering into the gastroduodenal perforation or dealing with any other peritoneal source of contamination. Standard textbook technique was adopted to close different types of incisions. All types of suture materials were used during closure (peritoneum was closed either with chromic catgut or as a part of mass closure with prolene). In fatty abdomen subcutaneous fat was apposed with chromic catgut 2-O. Interrupted silk stitches were used to close skin. A saline set drain was used whenever it was indicated. The tubes were brought out mainly through a separate wound. Drain tubes were attached to evacuated saline bag. At the end of operation abdomen was cleaned with dilute Cetrimide $(3 \% \mathrm{w} / \mathrm{v})$ and spirit soaked sterile swab. In some cases sterile gauze pieces were used to cover the wound which were kept in position with the help of elastoplast. In others, wound was covered with sterile surgical dressing. Dressings were left undisturbed unless it was felt necessary. Unusual pain in and around the wound was considered to be an indication of infection. As soon as the dressing was found to have soaked the wound was examined. A swab was taken from any discharge and was sent for bacteriological examination. Up to $100^{\circ} \mathrm{F}$ temperature within first three days after operation was considered as normal. Any persistent fever after that period was carefully and thoroughly investigated. Every patient got antibiotics postoperatively. The drainage tube was removed after cessation of discharge from 2 nd to 5th postoperative days. An open wound was covered with EUSOL soaked gauze, sterile cotton and dry sterile gauze and was kept in position with hypoallergenic tape. After studying all the cases data obtained were analyzed and presented in tabular and graphical form.

\section{Results}

Out of 100 patients with non-traumatic emergency laparotomy in this series, 40 cases were duodenal ulcer perforation, 5 cases were pre-pyloric and gastric ulcer perforation, 30 cases were acute appendicitis, 5 cases were burst appendix, 10 cases were ileal perforation, 3 cases were small intestinal obstruction due to bands and adhesions, 2 cases were volvulus of sigmoid colon, 4 cases were obstructed inguinal hernia, 1 case was generalized peritonitis due to puerperal sepsis (Table 1). 
Table 1: Name of the Diseases with their Operation

\begin{tabular}{|c|c|}
\hline Name of Disease & Name of operation \\
\hline Duodenal ulcer perforation & $\begin{array}{l}\text { Repair of perforation and } \\
\text { thorough peritoneal } \\
\text { toileting }\end{array}$ \\
\hline $\begin{array}{l}\text { Pre-pyloric and gastric ulcer } \\
\text { perforation }\end{array}$ & $\begin{array}{l}\text { Repair of perforation and } \\
\text { thorough peritoneal } \\
\text { toileting }\end{array}$ \\
\hline Acute appendicitis & Appendectomy \\
\hline Burst appendix & $\begin{array}{l}\text { Appendectomy and } \\
\text { peritoneal toileting }\end{array}$ \\
\hline Ileal perforation & $\begin{array}{l}\text { Repair and peritoneal } \\
\text { toileting }\end{array}$ \\
\hline $\begin{array}{l}\text { Small intestinal obstruction } \\
\text { due to } \\
\text { bands and adhesions }\end{array}$ & $\begin{array}{l}\text { Division of bands and } \\
\text { adhesions or resection and } \\
\text { anastomosis }\end{array}$ \\
\hline Volvulus of sigmoid Colon & Resection and anastomosis \\
\hline Obstructed inguinal hernia & $\begin{array}{l}\text { Herriotomy and } \\
\text { hemiorrhaphy }\end{array}$ \\
\hline $\begin{array}{l}\text { Generalized peritonitis due to } \\
\text { puerperal sepsis }\end{array}$ & $\begin{array}{l}\text { Laparotomy and peritoneal } \\
\text { toileting }\end{array}$ \\
\hline
\end{tabular}

Wound infection rate of specific type of operation were $12.5 \%, 20.0 \%, 6.6 \%, 40.0 \%, 40.0 \%, 33.3 \%$, $50.0 \%, 50.0 \%$, and $100.0 \%$ respectively. The overall surgical wound infection rate was $19.0 \%$ (Table 2).

Table 2: Rate of wound infection According to Disease

\begin{tabular}{lccc}
\hline Name of Disease & \multicolumn{2}{c}{ Infection } & Total \\
\cline { 2 - 3 } & Present & Absent & \\
\hline DU perforation & $5(12.5 \%)$ & $35(87.5 \%)$ & $40(100.0 \%)$ \\
$\begin{array}{l}\text { Pre-pyloric and } \\
\text { GU perforation }\end{array}$ & $1(20.0 \%)$ & $4(80.0 \%)$ & $5(100.0 \%)$ \\
$\begin{array}{l}\text { Acute } \\
\text { appendicitis }\end{array}$ & $2(6.7 \%)$ & $28(93.3 \%)$ & $30(100.0 \%)$ \\
$\begin{array}{l}\text { Burst appendix } \\
\text { Ileal perforation }\end{array}$ & $2(40.0 \%)$ & $3(60.0 \%)$ & $5(100.0 \%)$ \\
$\begin{array}{l}\text { Small intestinal } \\
\text { obstruction }\end{array}$ & $1(33.3 \%)$ & $2(66.7 \%)$ & $3(100.0 \%)$ \\
$\begin{array}{l}\text { Volvulus of } \\
\text { sigmoid Colon }\end{array}$ & $1(50.0 \%)$ & $1(50.0 \%)$ & $2(100.0 \%)$ \\
$\begin{array}{l}\text { Obstructed } \\
\text { inguinal hernia }\end{array}$ & $2(50.0 \%)$ & $2(50.0 \%)$ & $4(100.0 \%)$ \\
$\begin{array}{l}\text { Generalized } \\
\text { peritonitis }\end{array}$ & $1(100.0 \%)$ & $0(0.0 \%)$ & $1(100.0 \%)$ \\
Total & $\mathbf{1 9 ( 1 9 . 0 \% )}$ & $\mathbf{8 1 ( 8 1 . 0 \% )}$ & $\mathbf{1 0 0}(\mathbf{1 0 0 . 0 \% )}$ \\
\hline
\end{tabular}

\section{Discussion}

Surgical infection was studied by Lewis Pasteur and Joseph Lister hundreds of years ago and is still a subject of controversy and a problem all over the world ${ }^{5}$. Different workers in this field have given their own thoughts and ideas for the control of infection. In this series 100 cases are included. The patients are from all walks of life and are selected at random. They were admitted to Dhaka Medical College Hospital for emergency operations during the period June 1997 to July 1998. Operative treatment was carried out for different acute nontraumatic abdominal conditions as duodenal ulcer perforation, prepyloric and gastric ulcer perforation, ileal perforation, intestinal obstruction due to bands and adhesions, volvulus of the sigmoid colon, obstructive inguinal hernia and generalized peritonitis (Table 1).

In this study rate of infection in different operations are carried out. Clinical presentations of wound infection are also carefully noted. The findings of present study are compared with the results of study made by others ${ }^{6-9}$. Postoperative wound infection is still one of the major problems in the hospitals of this country and also continues to be a source of morbidity in the surgical patients. There are few reports on nosocomial infection in this country.

Patients are examined thoroughly to establish the diagnosis, and are resuscitated whenever necessary. The patients' age, physical build, general nutritional status, anaemia, jaundice and any septic focus are observed. Patients are asked for diabetic status, chronic pulmonary disease, concurrent diseases and use of steroids of immunosuppressive drugs. In relation to surgical wound infection, all of the above factors are very important. All patients are well-shaved and cleaned before operation. In the operation on a hair bearing area, the hair is usually shaved but rough shaving produces abrasions. Simple bathing in soap and water or detergent is all that is usually carried out. Any form of abrasion during shaving must be avoided as it may cause colonization of bacteria which results in higher wound infection rate.

The abdomen should be swabbed from the proposed line of incision to the periphery. Swabbing can not eradicate the whole bacterial population. The transient bacteria, which are on the surface, are killed by skin antiseptics but can not destroy the deep resident bacteria. In this series, most of the patients are washed by povidone iodine and/or spirit. Therefore, postoperative wound infection is not significantly higher. Povidone iodine is a safe and effective means of reducing wound sepsis following gastrointestinal surgery ${ }^{10}$. While dealing with a septic focus or a potential source of infection the wound must be carefully covered with a mop to avoid contamination of surrounding tissues ${ }^{11}$. Many surgeons wash hands and instruments after an intestinal anastomosis. They use new mops, gloves and sheets. Others not only wash their hands they also discard the used instruments and use new set for abdominal wound closure. 
The wound infections are evident between the period $3^{\text {rd }}$ to $6^{\text {th }}$ postoperative days. It indicates that the prime source of infection is the operation theatre. Antibiotics were used both in the pre- and postoperative period. The oral antibiotic replaced parenteral antibiotics when the patients were allowed to take food.

\section{Conclusion}

In conclusion the present study permits to conclude that the rates of wound infection of non-traumatic emergency laparotomy cases are frequently found in well-established tertiary care teaching hospital operation theatre settings. The most common are in ileal perforation and burst appendicectomy operation. Proper measures should be taken to tackle the situation.

\section{References}

1. Mc Minn RMH: Last's Anatomy, Regional and Applied, 9th ed. Churchill-Livingstone. Edinburgh 1994; 241-242, 295-299.
2. Williams, Peter L, Wan/vick R: Gray‘s Anatomy, 38th ed. Churchill-Livingstone. Edinburgh. 1995; 819-829.

3. Walter JB, Israel MS: General Pathology, 6th ed. Churchill-Livingstone Edinburgh. 1987; 81- 90, 97-107, 117-138

4. Mann CV, Russel RCG, Williams NS: Bailey and Loves, Short Practice of Surgery,21st ed. Chapman and Hall. London 1991; 1-11, 81-95.

5. Cotran RS, Kumar V, Robins SL: Pathologic basis of diseases, 5th ed. WB Saunders. USA 1994;86.

6. Jawetz E: Review of Medical Microbiology, 15th ed. Lanze Medical Publications. USA. 1982; 29, 117-154, 175-199, 227-241.

7. Vollum RL, Jamison DW, Cummins CS: Fairbrothers Textbook of Bacteriology, 10th ed, RW Fairbrother and William Heinemann Medical Books ttd. Great Britain. 1978; 42-46, 160-176.

8. Anderson W: Boyd's Pathology for the surgeon, 8th ed. Joint Indian American Textbook Programme. Philadelphia. 1974; 27-34.

9. Cruicshank R: Medical Microbiology, 12th ed. Vol 11. Churchill-Livingstone. Edinburgh 1975;170-198,428-436.

10. Dudley HAF: Hamilton Baily‘s Emergency Surgery, 11th ed. J. Wright and sons' ltd. Bristol. 1985;259-270.

11. Way LW: Current Surgical Diagnosis and treatment, 10th ed. Appleton and Lange. USA. 1994; 6-14, 40-64, 101$145,150-152$ 